\title{
Habitat variability and spatial assemblages of House Sparrows (Passer domesticus) along a gradient of urbanization
}

\author{
Manjula Menon, Prashanthi Devi, R.Mohanraj \\ Department of Environmental Management School of Environmental Sciences Bharathidasan University \\ Trichy-620024, Tamilnadu, India
}

\begin{abstract}
House sparrows (Passer domesticus) have declined world over, with their presence rarely seen in cities. Urbanization has lead to significant changes in the population biology of the species affecting their structure and community composition. We investigated the spatial and temporal distribution of House sparrow in various landscapes and the role of habitat attributes along a gradient of urbanization to uncover their possible sites of nesting and habitat preferences. With the study, we report that urban centres have lost favourable nesting habitats for House sparrows and they have locally migrated to the suburban and rural parts of the city. House sparrow abundance was higher in the suburban landscapes, compared to the rural and urban landscapes. House sparrow in the urban occupied a broader niche breath, than the populations in the sub urban and rural matrix. In the urban, the most preferred habitats of the House sparrow were residential areas with tiled and thatched roofs, in the sub urban, rice mills were most preferred and in the rural landscapes residential areas with tiled and thatched roofs and rice mills were equally preferred by the species. Our results revealed that along the gradient shrub cover, built up cover, socio economic status and economic prosperity were positively related to the abundance of House sparrow populations.

We summarize the possible decline of Passer domesticus due to lack of insectivorous and granivorous food in the urban, lack of nesting sites and non availability of straw. We suggest to the urban planners and city managers to built urban structures that are eco-friendly to sparrows which can host viable nesting sites for the species.
\end{abstract}

Key words: competition, extinction, landscape, homogenization, abundance

Accepted Date: 24 June 2013

\section{Introduction}

Ecologist have studied urban ecosystems in varied aspects, the most prominent being the impact on biodiversity (Middleton 1994, Wackernagel and Rees 1996). Urban ecosystems differ widely from natural ecosystems (Marzluff et al. 2001a, Chace and Walsh 2006), in the availability of food resources, pollution (Eeva et al.2000), climatic conditions and in the presence or absence of predators (Marzluff 2001). When natural habitats get replaced with exotic species it often leads to species extinction and biotic homogenization (Marzluff et al.2001, McKinney 2002, Olden et al. 2005) representing a threat to biodiversity at different scales (Turner et al. 2004). The best way to study the impact of urbanization on bird communities is studying through an urban rural gradient perspective (Bolger 2001).The urban rural gradient concept is important to study how urbanization is changing the patterns and processes across landscapes.

How are birds affected by urbanization? Urbanization effects arthropod abundance, the primary food for birds during the reproductive stages (McIntyre 2000) and changes in architecture affects the nesting. Of the several causes of bird species endangerment urbanization is said to rank the highest. According to the 2011, IUCN report, 1,253 species of birds are globally threatened with extinction, 189 are critically endangered, 381 species are endangered and 683 species are vulnerable.

As a result of urbanization, the once so common, the most dominant (Clergeau et al. 1998, White et al. 2005), and the most wide spread and abundant birds in the world the Passer domesticus have drastically declined (Summers-Smith 1988). The decline was first noticed in London where populations declined by $60 \%$ between 1994 and 2004 (Raven, Noble and Baillie, 2005) and Red Listed by Britain's Royal Society for Protection of Birds. In Edinburg the populations declined by 90\% (Summers-Smith 1999, Dott and Brown 2000, Mitschke, Rathje and Baumung, 2000) and in Netherland the sparrows are listed as endangered. Passer domesticus populations have declined by about $60 \%$ in urban and suburban since the mid 1970's (Robinson et al. 2005) due to the drastic alterations to the quality and composition of the urban landscapes. Any population under stress, when affected by detrimental factors in the environment, would badly affect the populations to cause local extinctions (Baker et al. 2005, Shaw 2009) and this would have lead to the large scale decline of the Passer domesticus. 
Several studies carried on Passer domesticus have cited varied reasons for their decline (SummersSmith 2003). In highly urbanized sites, pollution and anthropogenic disturbances have caused threat to those species that are sensitive to various stressor agents in the environment (McKinney 2002). Several studies have shown that the availability of insectivorous food for nestlings during the breeding season influences the breeding success of the sparrows. (Vincent 2005, Peach et al. 2008). The range of adult Passer domesticus is estimated to be $<2 \mathrm{~km}$ but during breeding season they forage within a distance of just $60-70 \mathrm{~m}$ from their nest site (Vincent 2005, Peach et al. 2008) and need to meet their food requirements within this limited range. How do these birds differ in tolerance to environmental factors when compared to other birds? Birds found commonly breeding in cities have broader environmental tolerance than closely-related species that do not breed in cities (Bonier et al. 2007b). Generalist species tend to fare better than specialists (Evans et al.2011). Researchers have reported that those species that dominate the urban with higher densities often leads to competitively exclude sensitive species such as the Passer domesticus (Huhtalo and Jarvinen, 1977, Bland 1979). It is necessary to extensively evaluate the effects of urbanization on the Passer domesticus species and also the common birds that are declining. The current study tries to address the possible variability and spatial assemblages of the Passer domesticus along a gradient of urbanization in one of the southernmost district of India, Tiruchirappalli. This paper focuses exclusively on the passerine bird House sparrow, which once dominated avifauna across the urban environment.

\section{Study Region}

\section{Materials and Methods}

The study was conducted at Tiruchirappalli in Tamilnadu which is an ancient historical city lies at North Latitude between 10 to 11-30' East and Longitude between 77-45' to 78-50' (Fig 1). Tiruchirappalli is the fourth largest city in Tamilnadu along the river Cauvery and the river Coleron, located at the geographic centre of the state with an area 4403.83 sq.km. Tiruchirappalli district is surrounded by Perambalur district in the north, Pudukkotai district in the south, Karur and Dindigul districts in the West and Thanjavur district in the east. Agriculture sector provides the major source of income to the population of the district. In Tiruchirappalli district, $1,86,778$ ha. (42.41 per cent to the total geographical area) of land is under irrigated area .The major source of irrigation is through wells and Canals. Throughout the season the city experiences hot and dry climate with maximum rain fall during the Northeast Monsoon. Urbanisation in the district registered an increasing trend over the years. The growth of urban population had gradually increased from 38.64 per cent in 1981 to 40.38 per cent in 2001. Urbanization and industrialization have triggered the infrastructure expansion and other commercial developments leading to large-scale landscape alterations and witnessing a high rate of urban agglomeration. These changing landscapes would mold bird species, their composition, habitat features and other functional aspects along the gradient.

\section{Study Design}

From October 2010 to September 2012, the population dynamics of the Passer domesticus were studied in Tiruchirappalli district of Tamilnadu along an urban rural gradient. One hundred sixty two point counts were located along the gradient of which 80 points were located in the urban, 21 in the sub urban, 61 in the rural matrix. The spacing of point counts varied along the gradient with points in the urban at every $500 \mathrm{~m}$, in the sub urban and rural at $800 \mathrm{~m}$ to assure survey independence (Ralph et al. 1996). At each point, Passer domesticus were surveyed using a fixed 25m radius point count method (DeGraaf et al. 1991, Ralph et al. 1996, Melles et al. 2003). Surveys were conducted between $6.00 \mathrm{am}$ to $9.00 \mathrm{am}$ on a monthly basis and Passer domesticus species and their habitat features were observed and recorded for ten minutes. Each stretch of the urban rural gradient was surveyed once a month, starting from the urban core to the rural. Bird richness estimation using a single-visit is an accepted method in urban areas (Jokimaki and Suhonen, 1998, Jokimaki and Kaisanlahti-Jokimaki 2003). The points were located using GPS, along eight different National Highways emanating from the city in various directions covering a total area of 71.47 sq.km. Survey was not carried out on rainy and windy days.

\section{Habitat Characterisation}

The community structure and the composition of Passer domesticus were studied in varied landuse patterns like Commercial, Residential, Commercial-residential, agriculture, plantations, wastelands, wetlands and Industrial. Preference were also given to areas with Tiled-Thatched Houses, areas in proximity to dams, Grocery Shops, holes of the high way fly over, coconut shells hanged from roofs of Houses. It was observed that rice mills and ancient monuments, in and around the district provided viable habitat for nesting of the sparrows, hence Rice mills and ancient monuments were included in the study. Habitat variables were measured in a 50m radius were built up cover, vegetation cover, predatory pressure and various anthropogenic activities that were supposed to link with abundance of sparrows. Vegetation structure was evaluated in terms of tree cover, shrub 
cover, tree species richness, tree abundance, shrub species richness, and shrub cover. Urban structures were evaluated in terms of built up cover and no. of built up structures. Human activity was described by pedestrian movement/min, vehicular traffic/min and noise levels measured in $\mathrm{db}(\mathrm{A}) / 10 \mathrm{~min}$. Predatory pressure was described by the presence or absence of predators, no. of predators, the proximity of nesting sites to road density and the presence of carnivores. Tree cover and built up cover was estimated using ARCGIS 10. Percent cover of herb cover and shrub cover was categorized using Braun-Blanquet categorical scale (Kent and Coker, 1992) within a 50m radius around each point count station. The cover scale was $0(<1 \%), 1(1-5 \%), 2(6-25 \%), 3(26-$ $50 \%), 4(51-75 \%)$, and $5(76-100 \%)$. Noise level was quantified along an urban rural gradient using sound level meter (model Lutron SL 4001) measured in decibels which was pre-calibrated to $94 \mathrm{~dB}$ before measurement. At random locations 60 observations were made for 15 minutes and sound levels were recorded for peak and non peak hours. Only the non peak hour values were used for analysis as this coincided with bird survey. The lowest socioeconomic level $(\mathrm{S}=1)$ was represented at locations with residential areas purely of tiled and thatched houses, socio economic status $(S=2)$ was given for a matrix of brick and thatched houses and the highest Socioeconomic level $(\mathrm{S}=3)$ was represented by sites with well built brick houses (Ian MacGregor-Fors.et al. 2011).

\section{Result and Discussions \\ The status of Passer domesticus populations in Tiruchirappalli}

The result shows that between 2010-2011 and 2011-2012 there has been a decline of 14.52\% in the Passer domesticus populations in the study area (Fig 2). The decline was highest in the urban landscape followed by the rural and the suburban landscape. The population of the species in Tiruchirappallai was found to be unstable and unevenly distributed along the gradient (Table 1). We found there was no significant monthly variations in the abundance of the species along the gradient but the interaction between years $(\mathrm{df}=22, \mathrm{f}=1.63$, $P=0.03$ ) was significant. We recorded significant differences in the interaction of Passer domesticus within the urban landscape $(\mathrm{df}=11, \mathrm{f}=6.33, \mathrm{p}=0.000)$, within the suburban $(\mathrm{df}=3, \mathrm{f}=100, \mathrm{p}=0.000)$, and within the rural landscapes $(\mathrm{df}=21, \mathrm{f}=8.25, \mathrm{p}=0.000)$. The frequency of occurrence of species was also higher in the suburban landscapes. In the study area Passer domesticus population were recorded in 38 locations which included 12 in the urban, 4 in the suburban and 22 in the rural matrix.

\section{Population dynamics of Passer domesticus along the urban landscape}

The urban environment has drastically modified the viable habitats of Passer domesticus and has affected their population dynamics. In the urban, habitat structure and composition plays an important role in governing the distribution of Passer domesticus. The species were recorded from 12 locations from the 80 sampled sites in the urban landscape. Zero density of birds were recorded in landuse patterns like plantations, purely commercial areas, wastelands and wetlands in the urban as they do not provide suitable nesting sites for the species. (Table 1). In the urban, the most preferred sites for sparrows are landuse patterns with a matrix of residential and commercial, purely residential areas, Rice Mills, Grocery Shops, Tiled-Thatched Houses and Ancient Temples. In Tiruchirappalli, higher abundance of Passer domesticus was recorded at Srirangam. Srirangam is an ancient historical city as old as 1300 years. The historical monuments at Srirangam provide suitable nesting sites for Passer domesticus as these monuments have the crooks and crannies of old age architecture. Summer-Smith (2003) discusses that reduction in the availability of suitable nesting sites in modem buildings and rehabilitation of old buildings would have declined the House Sparrow population.

In the urban, the highest density of birds was recorded during the month of June (Fig 3). The mean abundance of sparrows in the urban was recorded as $17.58 \pm 20.26$ individuals. The higher density of birds in the month of June can be attributed to the rapid movement of the Passer domesticus, both male and female in search of nesting materials and food. In the urban, Passer domesticus occupy a broader niche breath where B' $=0.283$ (Levins 1966) than its counterparts in the sub urban and rural matrix, reflecting a generalist pattern of resource use. In the urban, $30.55 \%$ of Passer domesticus used tiled and thatched houses for nesting, $16.66 \%$ used rice mills and ancient temples, $22.22 \%$ used a matrix of commercial and residential areas, $11.11 \%$ used purely residential areas, and $2.77 \%$ used grocery shops. In the urban, urban landscaping and built up cover governed the abundance of Passer domesticus species as $30.55 \%$ of the species were found in localities with tiled and thatched roofs. The relatively low densities of Passer domesticus in the city reflects stable low-density populations after a substantial decline (Vincent 2005).

\section{Population dynamics of Passer domesticus along the suburban landscape}

In the suburbs of Tiruchirappalli, the highest population of Passer domesticus were recorded along the Madurai National Highway which is an agricultural belt surrounded by numerous rice mills. From the 21 suburban sites studied, Passer domesticus population were recorded only at 4 locations with a mean population of $137.5 \pm 100.62$ and this recorded the highest density of sparrows in the study area (Table 2). The higher density 
of sparrows in this belt can be attributed to large acres of agricultural land and numerous rice mills along this stretch (Table 2). In the suburbs, Passer domesticus occupied a less broader niche breath than the urban sparrows where, $\mathrm{B}^{\prime}=0.104$, reflecting a generalist pattern of resource use.

Our study indicates that suburbs are the most ideal zones for sparrows, and is in accordance with other studies that emphasised the role of suburbs in providing unique habitats to large number of resident and migratory birds and would contain half of the species found in forested areas if they are less exposed to developmental activities (Blair 2004). In the sub urban, $40 \%$ of Passer domesticus used rice mills for nesting, $20 \%$ used Tiled and thatched houses, $9 \%$ used built structures and 30\% used agricultural landscapes. Higher density of sparrows in the suburban was observed during the month of April. In the suburb landscaping and built up cover significantly contributed to the abundance of Passer domesticus populations.

\section{Population Dynamics of Passer domesticus along the rural landscape}

Along the rural matrix, highest population of Passer domesticus was recorded along the Madurai stretch with a mean population of $25.09 \pm 31.56$ individuals and their abundance can be attributed to the large acres of agricultural land and rice mills along this stretch. In the rural, $42.19 \%$ of Passer domesticus populations were found in residential areas with tiled and thatched roofs and $20.32 \%$ were found in close proximity to rice mills (Table 3 ).

In the rural landscape, Passer domesticus occupy a narrow niche breath than the urban and sub urban sparrows where $\mathrm{B}^{\prime}=0.021$, reflecting a specialist pattern of resource use. In Tiruchirappalli, Passer domesticus were found nesting in the side wall holes of the high way flyovers which are designed to drain away water during the rainy seasons. Passer domesticus were also seen nesting in the dry coconut shells hanged in front of the houses, an age old practice to wade away ill effects surrounding a House. In the rural landscape, highest density of sparrows was recorded during the month of April and December and the populations were more evenly distributed than the urban landscapes.

In the rural landscapes, $20.31 \%$ of sparrows were recorded in residential areas that had higher number of thatched and tiled houses (Table 4). Our result shows that sparrow populations are most abundant in the agricultural landscapes in Tiruchirappalli. These agricultural landscapes provide them with abundant food resources, nesting materials and nesting habitats.

\section{Relation between habitat attributes and Passer domesticus abundance}

We found that in the urban two factors significantly contributed to Passer domesticus abundance mainly the Shrub cover $(\mathrm{r}=0.65, \mathrm{p}=0.01)$ and built up cover with tiled and thatched roofs $(\mathrm{r}=0.81, \mathrm{p}=0.01)$. Along the gradient that included the suburban and rural sites we found those factors that significantly contributed to Passer domesticus abundance were mainly the Shrub cover $(r=0.61, p=0.001)$ and built up cover with thatched roofs $(\mathrm{r}=0.58, \mathrm{p}=0.01)$. Number of vehicles, pedestrian movement, and proximity to roads, predators and noise levels did not show any significant correlation to Passer domesticus abundance. In the urban, sparrows depended heavily on shrubs for protein requirement (insect populations) especially for the nestlings and also depended on built up structures mainly tiled and thatched roofs for nesting, hence both these attributes are significantly correlated. Tiled and thatched roofs provide suitable nesting locations for birds and these are the most preferred habitat of the Passer domesticus. Cluster analysis showed differences in House sparrow assemblages across different sites along the urban-rural gradient. Urban sites were distinctly different from both suburban and rural sites (Fig 4). The shrubs that are heavily dependent by the Passer domesticus include Nerium oleander, Tabernaemontana divaricata, Tecoma stans (L.) Juss, Morinda coreia (Fig 5). These shrubs not only provide foraging grounds for the Passer domesticus but also conceal them from predators.

One major attribute that correlated with the abundance of Passer domesticus population especially in the urban Tiruchirappalli is the Socio economic status. The locations with built cover of tiled and thatched roofs, i.e., areas with low socio economic status had higher abundance of sparrows. Those areas in the urban that had moderate socio economic status ie, built cover with a matrix of tiled, thatched roofs and brick houses had moderate number of Passer domesticus populations and locations with high socio-economic status with only brick houses had no sparrow record.

\section{Conclusion}

Urbanization has negative impact on sensitive species that thrive in the urban ecosystem. Often habitat features and resource availability governs bird community structure and diversity along an urban rural gradient. Less adaptive species have progressively declined from the urban habitats paving way to the few selected ones that thrive well in the urban habitats. Population of Passer domesticus have drastically declined in the urban Tiruchirappalli compared to the sub urban and rural matrixes. The less abundance of Passer domesticus in the urban can be attributed to the non availability of the arthropod prey, a major component of the diet of nestling sparrows which have become unavailable in the urban settings. Shrub cover was found to be a significant factor 
governing the presence of Passer domesticus along an urban rural gradient. The abundance of Passer domesticus was higher in the suburbs of Tiruchirappalli, which are less exposed to developmental activities and are mostly covered by agricultural lands. These agricultural landscapes and the neighbouring shrub cover provide regular supply of insect food for the nestlings. The rice mills scattered along the suburbs provide nesting sites, and regular supply of granivorous food for the sparrows. This is in contrary to the studies on Passer domesticus conducted by (Carlos et al. 2010) where abundance of Passer domesticus were greater in the urban in cities and industrial areas, and lower numbers in suburban areas. Suburbs are often considered as habitat edges or ecotones that support relatively high diversity, as these regions have greater vegetative complexity and multi varied landscapes.

Most of the studies have related, tree cover as a major factor in maintaining bird species within urban areas (Gavareski 1976; Munyenyembe et al. 1989). A study conducted by Kher et.al (2010) shows significant positive correlation between the density of House Sparrow and herb diversity in Delhi. The presence of predators was found to be a detrimental factor for the survival of Passer domesticus population especially the exotic species like the House crows, cat populations, rodents and the Squirrels. Our results show that in Tiruchirappalli Passer domesticus populations are higher at sites with low socio economic status which is in accordance with the work conducted by (Droscher 1992, Bland 1998, Paston 2000, Robinson et al. 2005).

We found that urban centers have climatic variance that cannot be adjusted by all urban exploiters and some species are sensitive to changing climatic conditions as a result of global warming and are likely to be sensitive to demographic stochasticity. Species that are sensitive to urban attributes that relate to nesting, breeding and feeding, cannot tolerate the change and tend to decline. Most of the urban species are well adapted to the urban matrix and nest successfully on buildings and other urban structures, which make them ecologically successful from other species. Passer domesticus populations have declined from the urban environment due to their specialist form of nesting on the tiled and thatched roofs.

The main cause of decline in the population of Passer domesticus can be attributed to lack of nesting sites, non availability of granivorous and insectivorous food and non availability of straw for nesting. The availability of straw was found to be a major factor during the breeding period and nest construction. At nesting sites along the urban rural gradient, straw constituted the major ingredient of the nest. At instances of unavailability of straw, the nest built up was flat resting on the cemented parapet with not more than four strings. During the breeding period after successful coition, the female sparrow was found entering the nest of the male with a long piece of straw in her mouth that indicates the importance of straw in the biology of the species. The other associated reasons for decline are modernized granary, competitive exclusion from other urban species and large scale habitat alterations. Though there is an overall decline of Passer domesticus population along the urban rural gradient, few sparrow friendly habitats have been discovered along the rural matrix particularly in the proximity of rice mills, and in the side wall holes of highway flyovers in the district.

It is impossible for the human race to undo the negative effects of urbanization on biodiversity (Jokimaki, 1999, Turner et al. 2004). What is lost has been lost forever and to prevent further decline of the species we need to restore the degraded habitats and its biodiversity through well planned urban management policies and strategies, to bring the chirpings of sparrows back to our environment.

\section{Acknowledgements}

I Thank DST, Government of India for providing me the funding under the Women Scientist Scheme.

\section{References}

[1]. Anderson TR. 2006. Biology of the ubiquitous House Sparrow. From genes to populations - Oxford University Press, Oxford, 547 p.

[2]. Andren H. 1994. The effects of habitat fragmentation on birds and mammals in landscapes with different proportions of suitable habitat: a review. Oikos 71, 355-366.

[3]. Baker PJ, Bentley AJ, Ansell RJ and Harris S. 2005. Impact of predation by domestic cats Felix catus in an urban area. Mammal Review 35: 302-312.

[4]. Baskin Y. 1998. Winners and losers in a changing world. Bioscience 48, 788-792.

[5]. Blair RB. 2004. The effects of urban sprawl on birds at multiple levels of biological organization. Ecol Soc 9(2)

[6]. Bland R. 1979. An Urban Common Birds Census. Bird Study, 26, 68-69.

[7]. Bland RL. 1998. House sparrow densities in Bristol. Avon Bird Rep 1998:145-148

[8]. Bolger D. 2001. Urban Birds: Population, Community and Landscape Approaches. In Avian

[9]. Ecology and Conservation in an Urbanising World (Eds. Marzluff, J., Donnelly and Bowman). Kluwer Academic Publishers Group.

[10]. Bonier F, Martin PR, Wingfield JC. 2007b. Urban birds have broader environmental tolerance. Biol. Lett. 3, 670-673.

[11]. Carlos A, Chávez-Zichinellia, Ian MacGregor-Forsa, Patricia Talamas Rohanab, Ricardo Valdézb, Marta C. Romanob, Jorge E. Schondubea. 2010. Landscape and Urban Planning, 98 (2010) 183-189

[12]. Chace JF, Walsh JJ. 2006. Urban effects on native avifauna: a review. Landsc. Urban Plan. 74: 46-69.

[13]. Clergeau P, Savard JPL, Mennechez G, Falardeau G. 1998. Bird abundance and diversity along an urban-rural gradient:a comparative study between two cities on different continents. Condor 100:413-425.

[14]. DeGraaf RM, Geis AD, Healy PA. 1991. Bird population and habitat surveys in urban areas. Landscape Urban Plan. 21, $184-188$.

[15]. Dott H E M and Brown AW. 2000. A Major Decline in Passer domesticusin Central Edinburgh. Scottish Birds, 21, 61-68. 
[16]. Droscher VB. 1992. Unse Spatz piepst das Lied von Tod. Bunte 30:78-81

[17]. Eeva T, Tanhuanpaa S, Rabergh C, Airaksinen, S, Nikinmaa, M, Lehikoinen E. 2000. Biomarkers and fluctuating asymmetry as indicators of pollution-induced stress in two hole-nesting passerines. Func. Ecol. 14: 235-243.

[18]. Emlen JT. 1974. An urban bird community in Tucson, Arizona: Derivation, structure, regulation. The Condor, 76, $184-197$.

[19]. Evans KL, Chamberlain DE, Hatchwell BJ, Gregory RD, Gaston KJ. 2011. What makes an urban bird? Glob. Chang. Biol. 17, 3244.

[20]. Gavareski CA. 1976. Relation of park size and vegetation to urban bird populations in Seattle, Washington. The Condor, 78, 375382.

[21]. Haggard WH. 1990. Urban weather. Int. J. Environ. Stud. 36:73-82.

[22]. Harris LD. 1988. Edge effects and conservation of biotic diversity.Conservation Biology 2, 330-332.

[23]. Huhtalo H, Jarvinen O. 1977. Quantitative Composition of the Urban Bird Community in Tornio, Northern Finland. Bird Study, 24, $179-185$.

[24]. Jokimaki, J, Suhonen J. 1998. Distribution and habitat selection of wintering birds in urban environments. Landscape Urban Plan. 39, 253-263.

[25]. Jokimaki J. 1999. Occurrence of breeding bird species in urban parks: effects of park structure and broad-scale variables. Urban Ecosystems 3, 21-34.

[26]. Jokimaki J, Kaisanlahti-Jokimaki, ML. 2003. Spatial similarity of urban bird communities:

[27]. a multiscale approach. J. Biogeogr. 30, 1183-1193.

[28]. Lockwood JL, McKinney, ML. 2001. Biotic Homogenization. Kluwer Academic/Plenum Publishers, New York, New York, USA.

[29]. Marzluff JM, Bowman R, Donnelly R. 2001a. Avian Ecology and Conservation in an Urbanizing World. Norwell,MA: Kluwer Academic Publishers.

[30]. McDonnell MJ, Pickett STA, Pouyat RB. 1993. The application of the ecological gradient paradigm to the study of urban effects. In:McDonnell, M.J., Pickett, S.T.A. (Eds.), Humans as Components of Ecosystems. Springer-Verlag, New York, NY, USA, pp. $175-189$.

[31]. McIntyre N. 2000. Ecology of Urban Arthropods: A Review and a Call to Action. Entomological Society of America, 93, 825-835.

[32]. McKinney ML. 2002. Urbanization, biodiversity and conservation. BioScience 52,883-890.

[33]. Melles S, Glenn S, Martin K. 2003. Urban bird diversity and landscape complexity: Species-environment associations along a multiscale habitat gradient. Conservation Ecology, 7, 5 .

[34]. Middleton J. 1994. Effects of urbanization on biodiversity in Canada. In: Biodiversity in Canada: A Science Assessment for Environment Canada. Environment Canada, Ottawa, pp. 15-20.

[35]. Mitschke A, Rathjen H, Baumung S. 1999. Passer domesticusin Hamburg: Population, Habitat Selection and Conservation Status. (State Centre for Bird Conservation,Hamburg).

[36]. Munyenyembe F, Harris J, Hone J. 1989. Determinants of bird populations in an urban area. Australian Journal of Ecology, 14, 549-557.

[37]. Ortega-Álvarez R, MacGregor-Fors I. 2009. Living in thebig city: Effects of urban land-use on bird community structure,diversity, and composition. Landscape and Urban Planning, 90,189-195.

[38]. Peach WJ, Vincent K, Fowler JA, Grice PV. 2008. Reproductive success of Passer domesticusalong an urban gradient. Animal Conservation 11: 493-503.

[39]. Raven M J, Noble DG, Baillie SR. 2005. The Breeding Bird Survey 2004. Report No.10. (BTO/JNCC/RSPB)

[40]. Ralph CJ, Geupel, G.R., Pyle, P., Martin, T.E., DeSante, D.F., Milá, B., 1996. Manual de

[41]. metodos de campo para el monitoreo de aves terrestres. Gen. Tech. Rep. PSWGTR-159. Pacific Southwest Research Station, Forest Service, U.S. Department of Agriculture, Albany, CA.

[42]. Robinson R, Siriwardena G, Crick H. 2005. Size and trends of the House Sparrow Passer domesticus population in Great Britain. Ibis, 147, 552-562.

[43]. Sacchi R, Gentilli A, Razzetti E, Barbieri F. 2002. Effects of building features on density and flock distribution of feral pigeons Columba livia var. domestica in an urban environment.Canadian Journal of Zoology, 80, 48-54.

[44]. Summers-Smith D. 1988. The Sparrows. T and A D Poyser Ltd, Calton

[45]. Summers-Smith D. 1999. Current status of the House Sparrow in Britain. British Wildlife,

[46]. 381-386.

[47]. Summers-Smith, JD. 2003. The decline of the House Sparrow: a review. British Birds 95: 143-146.

[48]. Shaw LM. 2009. Investigating the role of socioeconomic status in determining urban habitat quality for the House Sparrow, Passer domesticus. PhD thesis; University of Exeter.

[49]. Turner WR, Nakamura T, Dinetti M. 2004. Global urbanization and the separation of human from nature. BioScience 54, 585-590.

[50]. Vincent KE. 2005. Investigating the causes of the decline of the urban House Sparrow Passer domesticus population in Britain. Leicester, De Montfort University. PhD: 303.

[51]. Wackernagel M, Rees W. 1996. Our Ecological Footprint:Reducing Human Impact on the Earth. The New Catalyst Bioregional Series, New Society Publishers, $160 \mathrm{pp}$.

[52]. White JG, Antos MJ, Fitzsimons JA, Palmer GC 2005 Nonuniform bird assemblages in urban environments: the influence of streetscape vegetation. Landsc Urban Plan 71:123-135.

Figures 


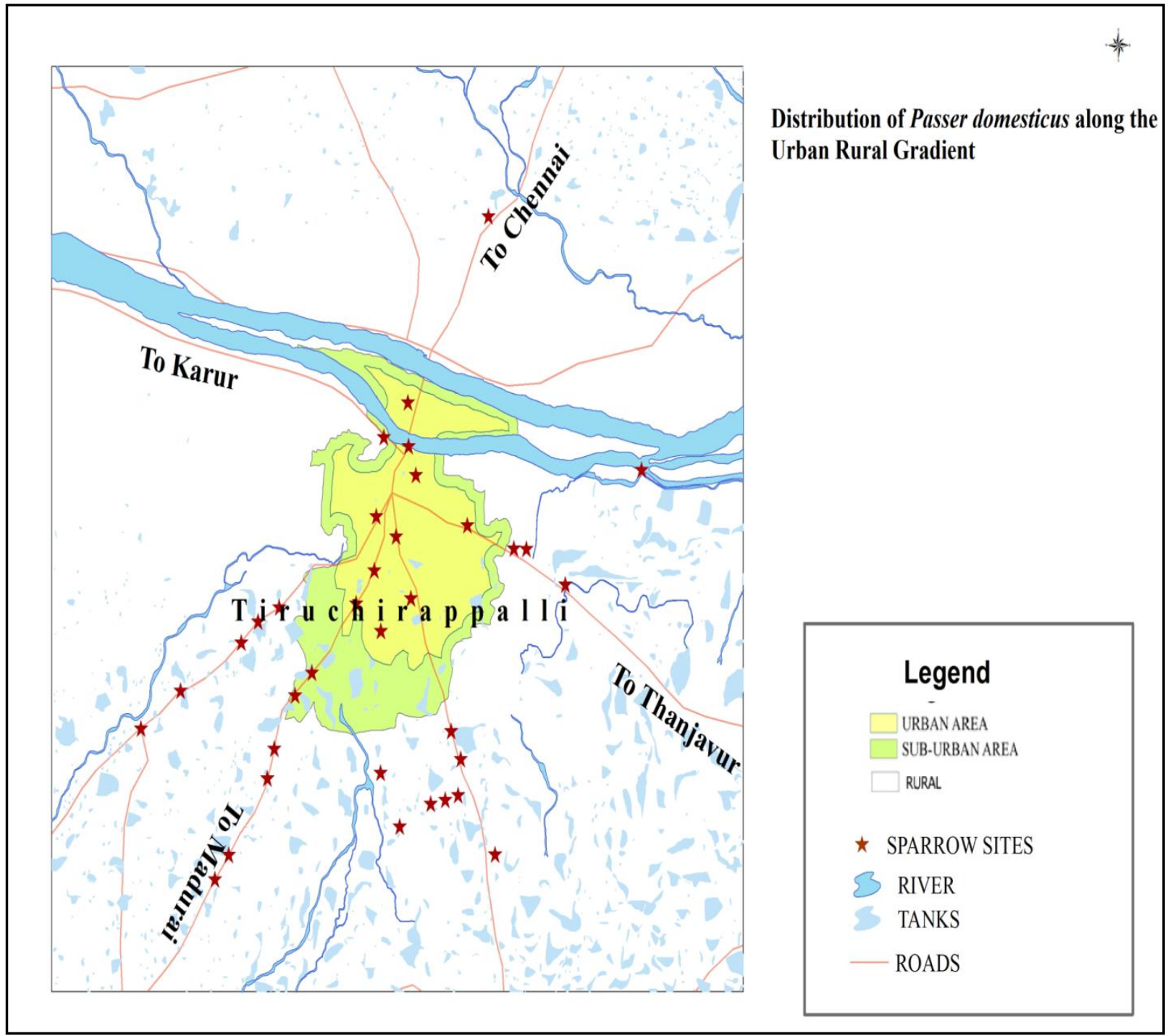

Fig 1. Distribution of Passer domesticus in the study area.

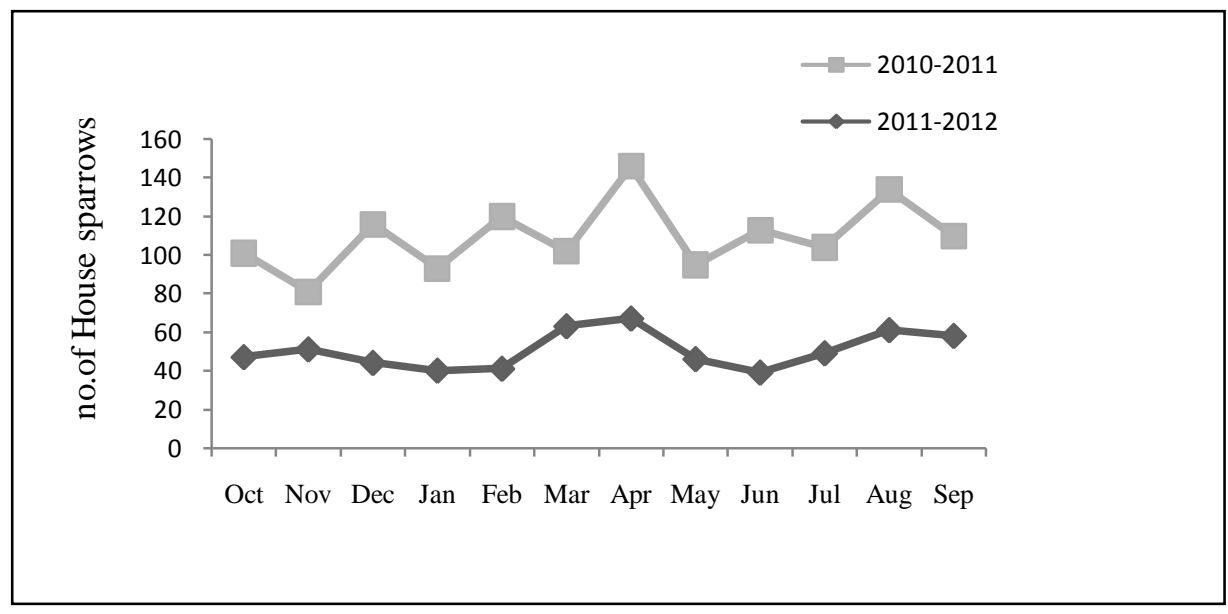

Fig 2. Temporal variation of Passer domesticus in the study area 


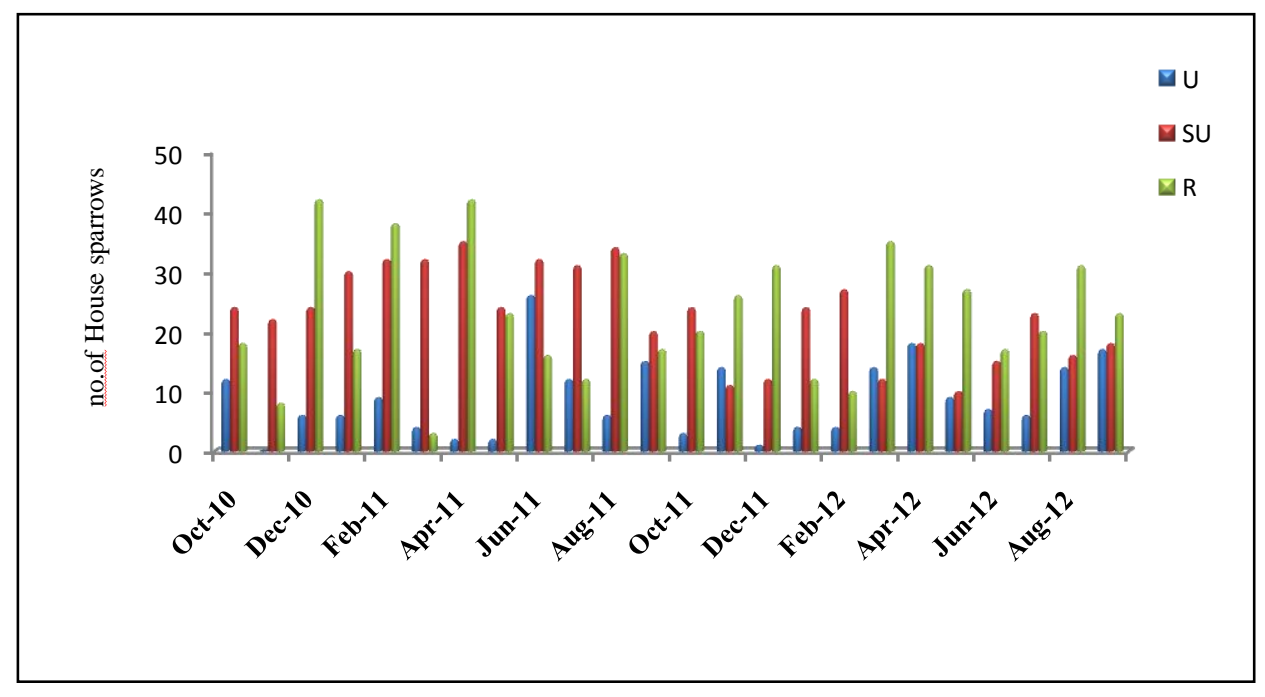

Fig 3. Monthly Variations in Passer domesticus populations along the gradient

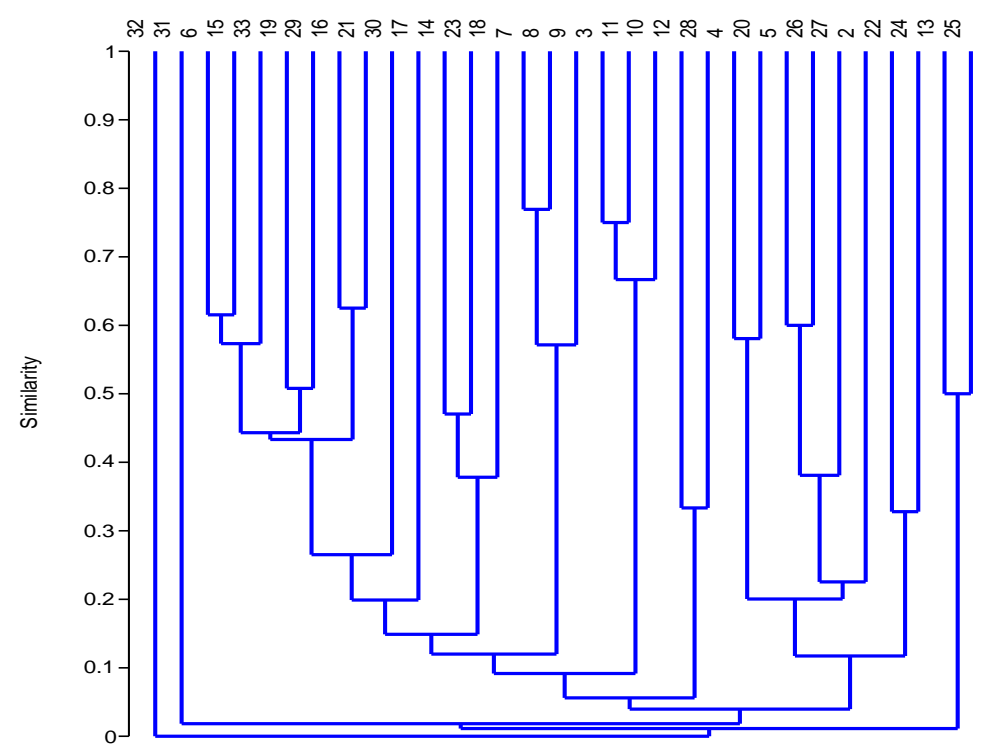

Fig 4. Cluster analysis (using the Bray-Curtis Similarity Index) showing differences in House sparrow assemblages across the urban rural gradient. 



Fig 5 Exotic Shrubs preferred by Passer domesticus

\begin{tabular}{|l|l|l|l|r|}
\hline $\begin{array}{l}\text { Location in } \\
\text { the urban }\end{array}$ & Code & Landuse & $\begin{array}{l}\text { Mean } \\
\text { population }\end{array}$ & $\begin{array}{l}\text { Frequency of } \\
\text { occurrence }\end{array}$ \\
\hline Pattabiraman Street & $\mathrm{U} 1$ & $\mathrm{R} / \mathrm{C}, \mathrm{T}, \mathrm{Ti}$ & $0.70 \pm 1.57$ & 0.20833 \\
\hline Sunder Nagar & $\mathrm{U} 2$ & $\mathrm{R} / \mathrm{C}, \mathrm{Ri}, \mathrm{Ti}, \mathrm{T}, \mathrm{G}$ & $0.16 \pm 0.56$ & 0.08333 \\
\hline E.Pudur & $\mathrm{U} 3$ & $\mathrm{R} / \mathrm{C}, \mathrm{Ri}, \mathrm{T}$ & $1.75 \pm 2.52$ & 0.45833 \\
\hline Kattur & $\mathrm{U} 4$ & $\mathrm{R} / \mathrm{C}, \mathrm{Ri}, \mathrm{Ti}$ & $0.58 \pm 1.71$ & 0.125 \\
\hline Thiruvenakoil & $\mathrm{U} 5$ & $\mathrm{R} / \mathrm{C}, \mathrm{T}, \mathrm{Ti}$ & $2.91 \pm 2.71$ & 0.66667 \\
\hline Kudumurthi bridge & $\mathrm{U} 6$ & $\mathrm{R}, \mathrm{Ri}, \mathrm{Ti}$ & $0.33 \pm 1.63$ & 0.04167 \\
\hline Crawford & $\mathrm{U} 7$ & $\mathrm{R} / \mathrm{C}, \mathrm{Ri}, \mathrm{Ti}$ & $0.20 \pm 1.02$ & 0.04167 \\
\hline Srirangam Kaveri & $\mathrm{U} 8$ & $\mathrm{R}, \mathrm{Ti}, \mathrm{T}$ & $1.16 \pm 2.42$ & 0.29167 \\
\hline Kajamallai & $\mathrm{U} 9$ & $\mathrm{R}, \mathrm{Ti}$ & $0.37+1.43$ & 0.125 \\
\hline Srirangam E.B.R & $\mathrm{U} 10$ & $\mathrm{R} / \mathrm{C}, \mathrm{Ti}, \mathrm{T}$ & $0.41 \pm 0.92$ & 0.20833 \\
\hline
\end{tabular}


Habitat variability and spatial assemblages of House Sparrows (Passer domesticus) along a gradient

\begin{tabular}{|l|l|l|l|l|} 
SIT & U11 & R, Ri, Ti & $0.04 \pm 0.20$ & 0.04167 \\
\hline Melapudhur & U12 & R/C, Ti & $0.12 \pm 0.61$ & 0.04167 \\
\hline
\end{tabular}

Table 1. Location of Passer domesticus in the urban and associated landuse pattern

(W-wasteland, R-residential, Ri-Rice mill, H-holes of High way flyover, C-commercial, T-temple, Ti-Tiled House, A-Agriculture, F-forest, G-Grocery Shops, Coc-Coconut shells hanged from roof, Bu-built structures).

\begin{tabular}{|l|l|l|l|l|}
\hline Location & Code & Landuse & Mean population & Frequency of Occurrence \\
\hline Kallikudi & SU1 & $\mathrm{Ri}, \mathrm{Ti}, \mathrm{R}$ & $0.33 \underline{ \pm 0.70}$ & 0.20833 \\
\hline Panjapur-1 & $\mathrm{SU} 2$ & $\mathrm{~A}, \mathrm{Bu}$ & $3.58 \pm 3.53$ & 0.625 \\
\hline Panjapur-2 & $\mathrm{SU} 3$ & $\mathrm{~A}, \mathrm{Ri}$ & $0.87 \pm 2.09$ & 0.20833 \\
\hline Panjapur-3 & SU4 & $\mathrm{A}, \mathrm{Ri}, \mathrm{Ti}$ & $18.12 \pm 7.07$ & 1
\end{tabular}

Table 2. Location of Passer domesticus in the sub-urban and associated landuse pattern

\begin{tabular}{|l|l|l|l|r|}
\hline Location & Code & Landuse & Mean Pop & Frequency of \\
\hline Mandyur & $\mathrm{R} 1$ & $\mathrm{R}, \mathrm{W}, \mathrm{Ri}, \mathrm{Ti}, \mathrm{A}, \mathrm{T}, \mathrm{Coc}$ & $0.29 \pm 0.99$ & 0.08333 \\
\hline Karunyanagar & $\mathrm{R} 2$ & $\mathrm{R}, \mathrm{Ri}, \mathrm{H}, \mathrm{Ti}$ & $3.95 \pm 3.32$ & 0.79167 \\
\hline Alanthur, & $\mathrm{R} 3$ & $\mathrm{R}, \mathrm{Ri} / \mathrm{H} / \mathrm{Ti}$, & $0.41 \pm 1.66$ & 0.08333 \\
\hline Fathima nagar & $\mathrm{R} 4$ & $\mathrm{R}, \mathrm{Ri}, \mathrm{H}, \mathrm{Ti}$ & $2.12 \pm 2.59$ & 0.5 \\
\hline Kariyamanikam & $\mathrm{R} 5$ & $\mathrm{R} / \mathrm{C}, \mathrm{W}, \mathrm{Ri}, \mathrm{Ti}, \mathrm{A}$ & $1.62 \pm 4.57$ & 0.16667 \\
\hline Mathur Vasan & $\mathrm{R} 6$ & $\mathrm{R}, \mathrm{Ri}, \mathrm{Ti}$ & $1.95 \pm 3.89$ & 0.25 \\
\hline Mount Tabor & $\mathrm{R} 7$ & $\mathrm{R}, \mathrm{Ri}, \mathrm{Ti}, \mathrm{A}$ & $0.33 \pm 1.63$ & 0.04167 \\
\hline MPR Mathur & $\mathrm{R} 8$ & $\mathrm{R}, \mathrm{Ri}, \mathrm{A}$ & $0.04 \pm 0.20$ & 0.04167 \\
\hline Atreya-Mathur & $\mathrm{R} 9$ & $\mathrm{R}, \mathrm{Ri}, \mathrm{Ti}$, & $0.25 \pm 1.22$ & 0.04167 \\
\hline Eenamkuluthur & $\mathrm{R} 10$ & $\mathrm{R}, \mathrm{Ri}, \mathrm{T}, \mathrm{Ti}, \mathrm{G}, \mathrm{A}$ & $0.91 \pm 3.43$ & 0.08333 \\
\hline Vannagkovil & $\mathrm{R} 11$ & $\mathrm{~W}, \mathrm{~T}, \mathrm{Ri}, \mathrm{A}$ & $0.5 \pm 1.44$ & 0.125 \\
\hline Nagamangalam & $\mathrm{R} 12$ & $\mathrm{~W}, \mathrm{H}, \mathrm{Ri}, \mathrm{R}, \mathrm{Ti}$ & $3.75 \pm 4.40$ & 0.625 \\
\hline Mullipatti & $\mathrm{R} 13$ & $\mathrm{Ri}, \mathrm{Ti}, \mathrm{A}, \mathrm{R}$ & $1.87 \pm 2.98$ & 0.41667 \\
\hline TNAU & $\mathrm{R} 14$ & $\mathrm{~A}, \mathrm{R}, \mathrm{Ti}, \mathrm{W}$ & $0.04 \pm 0.20$ & 0.04167 \\
\hline Kallani & $\mathrm{R} 15$ & $\mathrm{~W}, \mathrm{Ti}, \mathrm{R}, \mathrm{T}$ & $0.08 \pm 0.40$ & 0.625 \\
\hline OFD & $\mathrm{R} 16$ & $\mathrm{~W}, \mathrm{Ti}, \mathrm{R}, \mathrm{T}$ & $3.79 \pm 1.79$ & 1 \\
\hline VGP Township & $\mathrm{R} 17$ & $\mathrm{R}, \mathrm{W}$ & $0.12 \pm 0.61$ & 0.04167 \\
\hline MIET & $\mathrm{R} 18$ & $\mathrm{R}, \mathrm{Bu}$ & $0.12 \pm 0.61$ & 0.125 \\
\hline Thiruverambur & $\mathrm{R} 19$ & $\mathrm{C}$ & $0.33 \pm 0.96$ & 0.125 \\
\hline Thayanoor & $\mathrm{R} 20$ & $\mathrm{R}, \mathrm{W}$ & $0.16 \pm 0.63$ & 0.08333 \\
\hline Indira Ganeshan & $\mathrm{R} 21$ & $\mathrm{~A}, \mathrm{~W}$ & $0.12 \pm 0.61$ & 0.04167 \\
\hline Kallikudi SSC & $\mathrm{R} 22$ & $\mathrm{~W}, \mathrm{R}$ & $0.12 \pm 0.61$ & 0.04167 \\
\hline Olayiur & $\mathrm{R} 23$ & $\mathrm{~A}, \mathrm{R}$ & $0.16 \pm 0.81$ & 0.16667
\end{tabular}

Table 3. Location of Passer domesticus in the rural and associated landuse pattern

(W-wasteland, R-residential, Ri-Rice mill, H-holes of High way flyover, C-commercial, T-temple, Ti-Tiled House, A-Agriculture, F-forest, G-Grocery Shops, Coc-Coconut shells hanged from roof, Bu-built structures) 


\begin{tabular}{|l|c|l|l|}
\hline \multicolumn{4}{|c|}{ Landuse patterns preferred by the Passer domesticus } \\
\hline Landuse patterns & Urban & Suburban & Rural \\
\hline Rice Mills & $16.66 \%$ & $40 \%$ & $20.31 \%$ \\
\hline Ancient Temples & $16.66 \%$ & $1 \%$ & $6.25 \%$ \\
\hline Commercial-Residential & $22.22 \%$ & $0 \%$ & $1.56 \%$ \\
\hline Commercial & $0 \%$ & $0 \%$ & $0 \%$ \\
\hline Residential & $11.11 \%$ & $0 \%$ & $21.88 \%$ \\
\hline Tiled-Thatched Houses & $30.55 \%$ & $20 \%$ & $20.31 \%$ \\
\hline Grocery Shops & $2.77 \%$ & $0 \%$ & $1.56 \%$ \\
\hline Built structures & $0 \%$ & $9 \%$ & $0 \%$ \\
\hline Agriculture & $0 \%$ & $30 \%$ & $12.5 \%$ \\
\hline Wasteland & $0 \%$ & $0 \%$ & $7.81 \%$ \\
\hline Plantation & $0 \%$ & $0 \%$ & $0 \%$ \\
\hline Holes of Highway fly over & $0 \%$ & $0 \%$ & $6.25 \%$ \\
\hline Wetland & $0 \%$ & $0 \%$ & $0 \%$ \\
\hline Coconut shells hanged from roofs & $0 \%$ & $0 \%$ & $1.56 \%$ \\
\hline
\end{tabular}

Table 4. Landuse patterns preferred by the Passer domesticus 